\title{
FACTORS BEHIND TOURISTS' TRAVEL MOTIVATION: THE CASE OF THE GILAN REGION, IRAN
}

\author{
Yaser Ramazannejad ${ }^{1}$, Moslem Zarghamfard ${ }^{1}$, Arezoo Hajisharifi ${ }^{2}$, SAHand Azar ${ }^{3}$ \\ ${ }^{1}$ Department of Geography and Urban Planning, Faculty of Humanities, Tarbiat Modares University, Tehran, \\ Iran \\ ${ }^{2}$ Department of Geography and Urban Planning, Faculty of Geography, Tehran University, Tehran, Iran \\ ${ }^{3}$ Department of Geography and Urban Planning, Faculty of Geography, Urumia University, Urmia, Iran
}

Manuscript received: February 10, 2021

Revised version: June 26, 2021

\begin{abstract}
Ramazannejad Y., Zarghamfard M., Hajisharifi A., Azar S., 2021. Factors behind tourists' travel motivation: The case of the Gilan region, Iran. Quaestiones Geographicae 40(4), Bogucki Wydawnictwo Naukowe, Poznań, pp. 101-112. 2 figs, 6 tables.

AвstRAct: This research aims to identify the pull and push factors that are effective for tourists travelling to Gilan province and classifying their motivations into key factors. Data were collected using a questionnaire. A total of 20 motives, including 11 push factors and 9 pull factors, were investigated. The sample size of the study was 390 people. For data analysis, single-sample $t$-test and factor analysis were used. The results showed that the average total pull motive was greater than the push motive. Motives were divided into three main factors: 'nature-based tourism and spiritual regeneration', 'place dependency and the purchase of agricultural products' and 'lifestyle'. It should be noted that the 'nature-based tourism and spiritual regeneration' was found to be the most important factor for travelling to Gilan province.
\end{abstract}

KEYWORDS: tourism, motivation, pull and push factor, Gilan, Iran

Corresponding author: Moslem Zarghamfard, Department of Geography and Urban Planning, Faculty of Humanities, Tarbiat Modares University, Jalal-Al Ahmad, Tehran, 11-888, Iran (Islamic Republic of); e-mail: zarghamfard.moslem@gmail.com

\section{Introduction}

In the recent decades, various strategies have been considered for economic development across the world. One of these strategies, among many others, is tourism development (He 2003; Wang 2006; Ryan et al. 2009). Tourism can be considered as one of the most important activities of today's people, which in addition to making dramatic changes in the earth's landscape, transforms the political, economic and cultural situations, as well as the lifestyle of human beings (Arlinghaus, Mehner 2004; Sharpley 2008). Today, tourism is regarded by nations as a social and economic phenomenon and has experienced a continuous and increasing growth in the recent decades, so that it has turned to be one of the fastest growing economic sectors (UNWTO 2012) and plays a key role in the development of countries, regions and villages; this role is more eminent in economic growth and leads to employment and income for tourism destinations (Noriko, Mototsugu 2007; Lee, Chang 2008; Deller 2010; Schubert et al. 2010; Seetanah 2011; Ridderstaat et al. 2014; Bouzarjomehri 2014; Sharpley, Telfer 2015; Habibi et al. 2018).

The urbanisation trend in Iran has intensified in the recent decades (Qelichi et al. 2017; 
Zarghamfard et al. 2019), and the majority of the country's population has become urbanised (Shia 2003: 38). The need to create new urban land uses has gradually reduced the share of green space and urban gardens, resulting in limited human access to nature (Moureh 1994: 72). The inhabitants of modern cities not only need food, but also a suitable living space, a calm environment and clean breathing air (Shakooei 1979: 65; Durbarry 2002). As a result of changes caused by industrial events, cities face problems such as land shortages, slums, health issues, population and building density, environmental pollution and so on (Shia 2003: 42).

The current physical and social situation in Iranian cities, especially metropolises (as origins of tourist travel in Iran), is such that it has caused people to travel to the countryside and other provinces on vacation, to escape from the urban living conditions. Thus, Gilan province has been selected as a tourist destination due to its many tourist attractions. In fact, the tourism features of Gilan act as pull factors. The reason for the high volume of tourist trips to Gilan goes back to its environmental conditions. Gilan province attracts tourists from different places in Iran all the year round.

Despite the availability of entrepreneurial opportunities in the tourism industry in Gilan province, many educated and young people have been emigrating from this province (Gnoth 1997; Esfandiari, Nabieian 2000; Jomepour 2007; Shamsoddini, Gorjian 2010; Aghayarihir et al. 2018). Of course, besides such opportunities, there are many economic problems in the regional structure of Gilan and therefore, paying special attention to tourism in this province is essential for employment creation and economic development.

So far, no study has been done on the motivations for travelling to Gilan province. The purpose of this study is to identify the motivational pull and push factors that affect tourist travel to Gilan province, as well as to classify these motives based on the main factors. Therefore, identifying and classifying the motives for travelling to Gilan provides a framework for understanding them and paves the way for future research. On the other hand, it leads to identifying destinations that have the potential to attract tourists. This recognition can improve the destination characteristics, infrastructure development, services development, marketing strategies to compete with other tourism destinations and increase customer satisfaction.

\section{Literature review}

One of the concerns in the field of tourism is the reason for travel and the choice of destination. In this regard, the following questions may arise in the minds of researchers and marketers: why do tourists travel, why do they choose a particular destination and what motivation is effective in choosing a particular destination (Heitmann 2011; Pereira et al. 2019; Y1ld1z, Khan 2019; Liao, Chuang 2020). Each destination offers different products and services to attract tourists, and each tourist has the opportunity to choose from among different destinations. Therefore, the reasons for travelling and the choice of different destinations should be measured as the variables affecting tourist motivations for choosing different destinations. For this reason, motivation has a special significance in tourism studies and a variety of research has been done in this regard (Macintosh, Goeldner 1986; Hua, Yoo 2011; Podoshen 2013; Wu, Pearce 2014; Zhang, Peng 2014).

Motivation has been defined as the internal status of a person that propels him/her towards a need (Crompton, McKay 1997). It is the need that drives an individual to act in a certain way to achieve the desired satisfaction (Kim, Ritchie 2012) as forces that reduce a state of tension. This state gives rise to a need that stimulates an attitude or behaviour. In this regard, tourist motivations have been the central focus of tourism research for several decades (Huang 2010). With respect to travel, motivations are related to a set of needs that cause a person to participate in tourism activity (Park, Yoon 2009).

Hence, motivation plays a significant role in influencing travel decisions and tourist behaviour (O' Leary, Deegan 2005), as it explains why people travel, why they engage in the activities they do while on holiday and why they select a specific destination (Heitmann 2011). Planning for tourism development requires attention to the necessities, characteristics and market demands. In this regard, recognising the motivation of tourists to travel is important as a marketing 
strategy (Correia et al. 2007; Zhang, Peng 2014; Yousaf, Xiucheng 2018) and facilitates tourism planning (Wu, Pearce 2014). Indeed, the existence of different motivations, specifies the necessity of planners' and tourism administrators' awareness of these characteristics (Truong et al. 2017; Vigol et al. 2018).

In this regard, studying the customers of the tourism market and identifying their motives in choosing their tourism destination is important (Rivera et al. 2010). Tourists choose a tourist destination inspired by different motives. In fact, presenting a new product on the target markets and attracting new and old customers in a systematic process requires recognising tourists' motivations. There are two different reasons why people travel and what motivates people to travel to a specific place. The first question is about the traveller's psychological perception, while the second question is about the attractiveness of the destination. As a result, to satisfy travellers' desires and motivational needs and attract them to a special destination, we must pay attention to the pull and push factors (Pan, Ryan 2007; Mahmoudzadeh et al. 2014: 112).

The push and pull factors are fundamental for explaining why people travel (Jang et al. 2009). Push and pull motivation has been accepted as a framework for explaining tourist's motivation (Jang, Cai 2002; Gu et al. 2019). Pull factors are related to the tangible characteristics of a destination (lifestyle, landscape, events, culture, heritage or climate), thus providing an extrinsic travel motive to the tourist. Push factors, on the other hand, are related to personal, intrinsic motives for travelling such as adventure, relaxation, evasion and escape from routine. Push factors are mostly related to the decision to travel, while pull factors are related to the choice of a specific destination (Wu, Pearce 2014; Luo, Ren 2020). Uysal and Jurowski (1994) stated that most push factors are intrinsic motivators, such as the desire for escape, rest and relaxation, prestige, health and fitness, adventure or novelty and social interaction (Uysal, Jurowski 1994). Escape from a perceived mundane environment: A temporary change of an environment is a frequently expressed motive for travel (Crompton 1979). Even the most prized living environments sometimes become mundane to those living there. Crompton's research could not define a single optimum type of environment that facilitates escape. The critical ingredient is only that the context of the vacation or tourism opportunity should be physically and socially different from the environment in which the prospective tourist normally lives (Crompton 1979). Push factors relate to the importance of the home environment and its conditioning on the potential tourist and result in noting various needs and pressures that motivate the potential tourist to act. The subsequent act of destination selection and travel is analysed in terms of its ability to correspond to identifiable needs and pressures (pull factors) (Guha 2009: 24).

Many studies have been conducted on travel motives in order to recognise and meet the needs of tourists (Jang, Wu 2006). In this regard, most research related to the motivation of travel has been carried out based on the pull and push theory (Crompton 1979; Al-Haj Mohammad, Matsom 2010; Taher et al. 2015). According to Utama et al. (2014), motivational push factors affect the satisfaction of senior foreign tourists vacationing in Bali, comprising (1) the push to visit new places, (2) the push to gain new knowledge and experience and (3) the push to get out of the daily routine. In addition, motivational pull factors also affect the satisfaction of senior foreign tourists vacationing in Bali, comprising (1) health facilities, (2) the quality of travel agency services and (3) the quality of tour guides. Al-Haj Mohammad and Matsom (2010) examined the travel motivations of foreign tourists to Jordan. They found eight push factors (fulfilling prestige, enhancing relation, seeking relaxation, enhancing social circles, sightseeing, fulfilling spiritual needs, escaping from daily routine and gaining knowledge) and eight pull factors (events and activities, easy and affordable access, history and culture, variety seeking, adventure, natural reserves, heritage sites and sightseeing variety). Devesa et al. (2009) have identified four clusters of rural tourists. The first consists of tourists seeking tranquillity and interaction with nature, the second relates to cultural visits, the third consists of rural tourists interested in gastronomy and visiting natural parks, and the fourth relates to return tourists that visit the rural to see friends and family or rest in their own house. Sangpikul (2009) compared travel motivations of international Asian and European tourists with Thailand. The study identified three push factors (novelty seeking, 
escape and socialisation) and three pull factors (a variety of tourist attractions and activities, travel costs, safety and cleanliness).

Reviewing theoretical literature, we identified two categories of factors behind travel motivation: push factors and pull factors (Fig. 1). It can be stated that the problems caused by urban life are the most important push factors. In big cities, life stress is high and citizens feel deprived of comfort and tranquillity. In addition, air pollution often caused by industrial activities as well as transport is always a major challenge. Because of overcrowding and overuse of private cars, we often face heavy traffic in large cities (especially in third-world countries). Traffic increases mental fatigue and wastes citizens' time. In addition, people in big cities spend a lot of time at work, so they have less free time to rest. Taken together, these issues have created a kind of aversion to large cities and it has made citizens more willing to travel to other places. The above-mentioned are some of the main factors of citizens' desire to travel to tourist places. In fact, pull factors encourage people to travel to tourist destinations. When citizens decide to travel, they consider various factors to choose the travel destination. Natural assets are one of the most important. The existence of natural attractions frees citizens from urban life. Moreover, it strengthens them psychologically. In addition, clean air and quiet spaces are very important for citizens because they seek comfort, and such spaces can meet their needs. Human, geomorphological, historical and archaeological attractions also play a role in choosing a travel destination. In general, push and pull factors are both travel stimuli. Citizens intend to travel owing to urban life problems and recover psychologically by visiting the desired environments. Then they return to the city to continue living and working.

\section{Materials and methods}

In this study, data were collected using a questionnaire consisting of three modules. The first module focused on the profile of tourists in Gilan province. The second module focused on the travel patterns of tourists. The third module focused on the motivations of tourists for travel to Gilan.

In the present research, data were collected using a three-part questionnaire. The first part focused on the characteristics of tourists visiting Gilan province. The second and third parts focused on tourists' travel patterns and their motives for travelling to the province. In designing the motivations, the theory of pull and push factors was considered. In all, 20 motivation factors, including 11 push factors and 9 pull factors, were used (Table 1). For designing the questionnaire and selecting the motivations, previous research (Beard, Ragheb 1983; Correia et al. 2007; Esichaikul 2012; Francioni Kraftchick et al. 2014; Prayag, Hosany 2014; Rid et al. 2014; Wu, Pearce 2014; Zhang, Peng 2014; Yosefi, Marzuki 2015; Bideci, Albayrak 2016; Lai et al. 2020) was used. Nevertheless, the conditions of the origin and destination points of the journey were considered, and the pull and push factors were found to be compatible with the conditions of the origin and destination points. Motivations were measured through a 5-point Likert scale. In addition, 390 subjects were selected based on the Cochran sampling method. The questionnaires were provided to the tourists visiting Gilan province, and they completed them in person. Since the researcher was present at the time of completing the questionnaire, explanations were provided if necessary. In general, by studying the world literature, a set of factors were compiled, and then factors that were compatible with the conditions

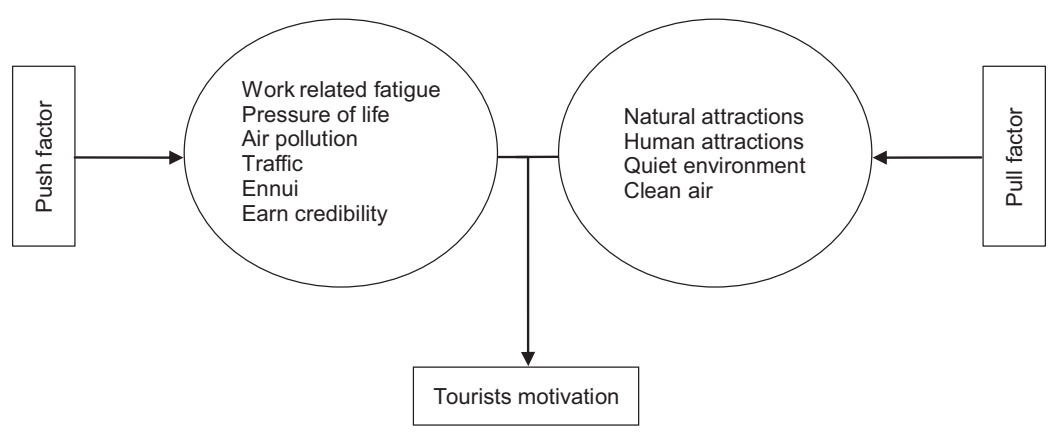

Fig. 1. Travel motivations. Source: own compilation (2020). 
Table 1. Push and pull motivational factors.

\section{Push factors}

Sense of dependency

Purchase of agricultural products at cheaper price

Direct purchase of agricultural products

Interest in visiting a village of birthplace or family hometown

Desire to meet family, friends and relatives

Desire to experience excitement and adventurous situations

Overcoming stress and renewing mental health in a space away from

usual tensions of life

Desire to escape from ongoing busy life and everyday homogeneity

Create happy and fun moments with your family or friends

Opportunities to get acquainted with other cultures

Desire to interact with local residents of Iran and Gilan province were selected to advance the research.

Data were collected between June and September 2019 by a convenience sampling method. After the elimination of incomplete questionnaires, 390 usable questionnaires were included in the analyses and analysed by the SPSS software. Then the descriptive statistics of the characteristics of tourists as well as their travel patterns were evaluated by frequency and percentage. One-sample $t$-test was used for statistical analysis and investigation of the role of pull
Pull factors

Presence of beautiful natural landscapes

Existence of handicrafts

Abundance of agricultural products

Existence of sea

Diverse agricultural activities

Existence of many rivers

Existence of forest

Existence of human perspectives

Existence of traditional lifestyle

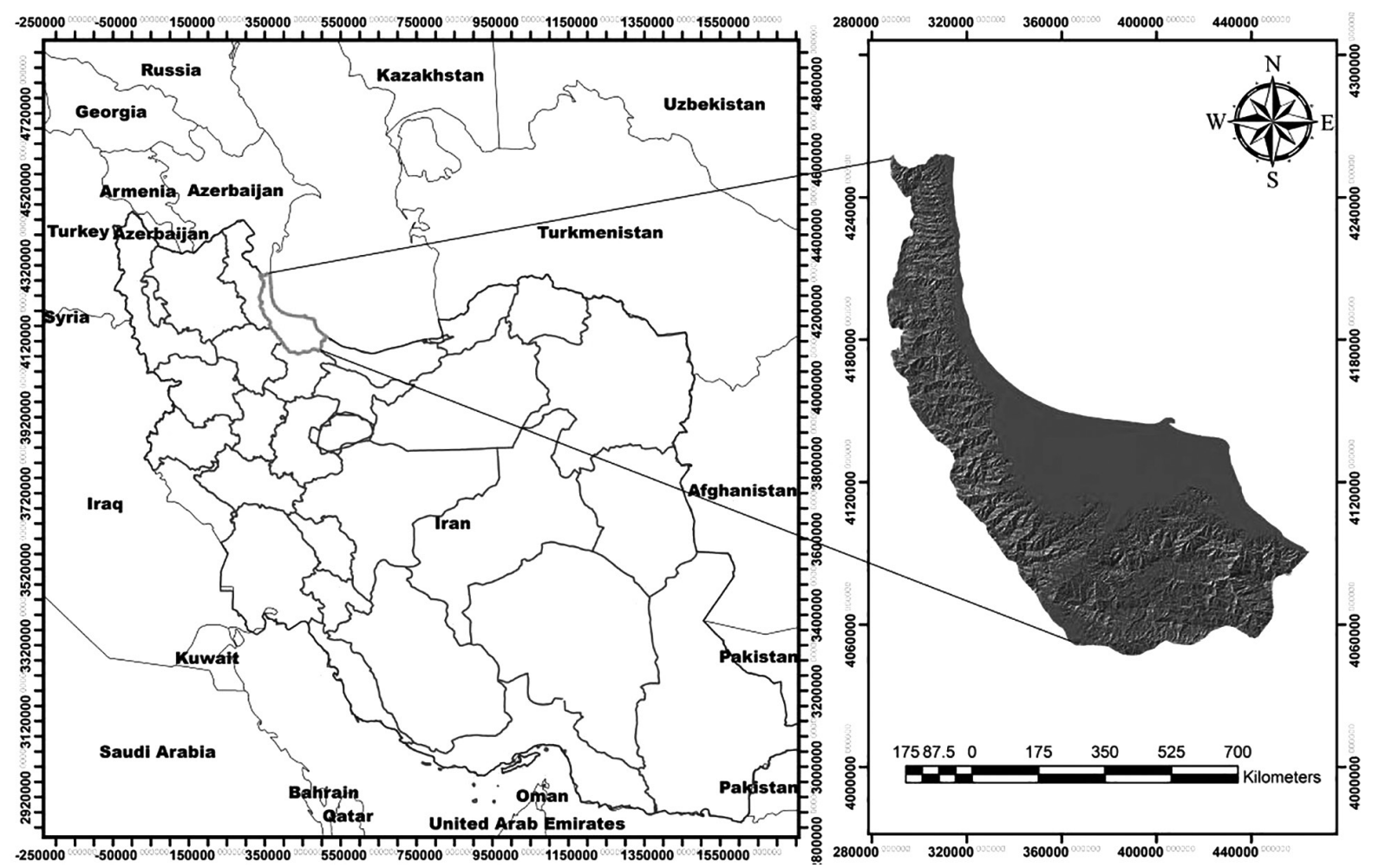

Fig. 2. Geographical location of the studied area. Source: own compilation (2020). 
area is one among the 31 provinces of Iran and it covers about $0.9 \%$ of the country. Gilan province shares borders with Ardabil on the west, Mazandaran on the east, Zanjan on the south and the Caspian Sea. It consists of three parts: coastal, plain and mountainous. Owing to its geographical location in the southwest of the Caspian Sea (Fig. 2), Gilan province is one of the most important regions of Iran and one of the most beautiful provinces of the country in terms of nature and tourism (Safavi et al. 2017); it has unique historical and natural assets such as massive forests, large paddies, bird habitats, ponds and rivers, beautiful beaches of the Caspian Sea and valuable historical cultural monuments dating back to thousands of years (Aghajani, Azkia 2015).

\section{Findings}

Table 2 shows the tourist profiles. Descriptive analysis shows that in terms of gender, $65.4 \%$ was male and $34.6 \%$ was female. In terms of age, $8.2 \%$ of tourists were aged between 15 and $24,23.6 \%$ were between 25 and 34, 34.4\% were between 34 and $44,27.4 \%$ were between 45 and 54 , and $6.4 \%$ were more than 55 years old. The marital status of the tourists was $86.2 \%$ married and $13.8 \%$ single. The educational levels of the tourists were sub-diploma $15.1 \%$, diploma $18.2 \%$, associate degree $16.7 \%$, MS $35.9 \%$ and MA 14.1.

Table 3 shows tourists' travel patterns. Among 390 samples, 192 tourists travelled to Gilan once and 198 tourists travelled to Gilan more than

Table 2. Profile of tourists.

\begin{tabular}{|l|l|r|r|}
\hline Variable & \multicolumn{1}{|c|}{ Values } & Frequency & $\%$ \\
\hline \multirow{4}{*}{ Gender } & Female & 135 & 34.6 \\
\cline { 2 - 4 } & Male & 255 & 65.4 \\
\hline \multirow{5}{*}{ Marital status } & $15-24$ & 32 & 8.2 \\
\cline { 2 - 4 } & $25-34$ & 92 & 23.6 \\
\cline { 2 - 4 } & $35-44$ & 134 & 34.4 \\
\cline { 2 - 4 } & $45-54$ & 107 & 27.4 \\
\cline { 2 - 4 } & +55 & 25 & 6.4 \\
\cline { 2 - 4 } & Married & 336 & 86.2 \\
\hline \multirow{5}{*}{ Single } & 54 & 13.8 \\
\cline { 2 - 4 } & Sub-diploma & 59 & 15.1 \\
\cline { 2 - 4 } & Asploma & 71 & 18.2 \\
\cline { 2 - 4 } & MS & 65 & 16.7 \\
\cline { 2 - 4 } & MA & 55 & 35.9 \\
\hline
\end{tabular}

Source: own compilation (2020). once. The tourists' stay in the province included villa rental $(26.4 \%)$, private villa $(10.3 \%)$ and camping (63.3\%). Tourists' familiarity with Gilan was via Internet $(2.8 \%)$, local friends and acquaintances $(53.3 \%)$, media $(6.2 \%)$ and accidental $(37.7 \%)$. In terms of times of travel, the statistics showed weekends (3.1\%), weekdays (19.7\%), holidays $(44.4 \%)$ and free time (32.8\%). Travel companions included $2.3 \%$ alone, $85.1 \%$ with family and $12.6 \%$ with friends.

Table 4 shows the results of a one-sample $t$-test for the pull and push motivational factors. Based on the results, the mean of the total push factors is equal to 2.888 and the following motives had the highest mean: Desire to escape from the ongoing busy life and everyday homogeneity, Create happy and fun moments with family or friends, Desire to interact with local residents, Desire to experience excitement and adventurous situations, Overcoming stress and renewing mental health in a space away from the usual tensions of life, Opportunities to get acquainted with other cultures, Sense of dependency, Direct purchase of agricultural products, Purchase of agricultural products at cheaper price, Desire to meet family, friends and relatives and Interest in visiting a village of birthplace or family hometown. On the other hand, the mean of the total pull factors is equal to 3.511 and the motives

Table 3. Tourists' travel patterns.

\begin{tabular}{|c|c|c|c|}
\hline Variable & Values & Frequency & $\%$ \\
\hline \multirow[t]{2}{*}{ Travel times } & First time & 192 & 49.2 \\
\hline & More than once & 198 & 50.8 \\
\hline \multirow{4}{*}{$\begin{array}{l}\text { Residence } \\
\text { location }\end{array}$} & Villa rental & 103 & 26.4 \\
\hline & Private villa & 40 & 10.3 \\
\hline & Camping & 247 & 63.3 \\
\hline & $\begin{array}{l}\text { Home relatives } \\
\text { and friends }\end{array}$ & 0 & 0 \\
\hline \multirow{4}{*}{$\begin{array}{l}\text { Familiarity with } \\
\text { the destination }\end{array}$} & Internet & 11 & 2.8 \\
\hline & $\begin{array}{l}\text { Local friends and } \\
\text { acquaintances }\end{array}$ & 208 & 53.3 \\
\hline & Media & 24 & 6.2 \\
\hline & Accidental & 147 & 37.7 \\
\hline \multirow{4}{*}{$\begin{array}{l}\text { Travel time } \\
\text { priority }\end{array}$} & Weekends & 12 & 3.1 \\
\hline & Weekdays & 77 & 19.7 \\
\hline & Holidays & 173 & 44.4 \\
\hline & Free time & 128 & 32.8 \\
\hline \multirow{3}{*}{$\begin{array}{l}\text { Travel compan- } \\
\text { ions }\end{array}$} & Alone & 9 & 2.3 \\
\hline & Family & 332 & 85.1 \\
\hline & Friend & 49 & 12.6 \\
\hline
\end{tabular}

Source: own compilation (2020). 
Table 4. One sample T-tests between push and pull motivational factor.

\begin{tabular}{|c|c|c|c|}
\hline Factor & Motivation & Mean & $\mathrm{t}$-value \\
\hline \multirow{12}{*}{ 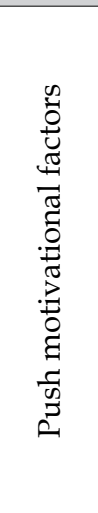 } & Sense of dependency & 2.286 & -24.476 \\
\hline & Purchase of agricultural products at cheaper price & 1.713 & -34.686 \\
\hline & Direct purchase of agricultural products & 2.033 & -33.736 \\
\hline & Interest in visiting village of birthplace or family hometown & 1.526 & -39.208 \\
\hline & Desire to meet family, friends and relatives & 1.620 & -42.807 \\
\hline & Desire to experience excitement and adventurous situations & 3.680 & -13.346 \\
\hline & Overcoming stress and renewing mental health in space away from usual tensions of life & 3.186 & -17.399 \\
\hline & Desire to escape from ongoing busy life and everyday homogeneity & 4.506 & -9.256 \\
\hline & Create happy and fun moments with your family or friends & 4.500 & -5.956 \\
\hline & Opportunities to get acquainted with other cultures & 2.846 & -22.680 \\
\hline & Desire to interact with local residents & 3.873 & -14.105 \\
\hline & Total & 2.888 & -51.911 \\
\hline \multirow{10}{*}{ 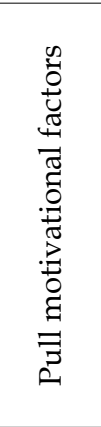 } & Presence of beautiful natural landscapes & 4.593 & -7.473 \\
\hline & Existence of handicrafts & 2.246 & -25.936 \\
\hline & Abundance of agricultural products & 1.740 & -34.736 \\
\hline & Existence of sea & 4.780 & -5.662 \\
\hline & Diverse agricultural activities & 2.166 & -30.989 \\
\hline & Existence of many rivers & 4.620 & -7.502 \\
\hline & Existence of forest & 4.586 & -7.702 \\
\hline & Existence of human perspectives & 4.326 & -11.185 \\
\hline & Existence of traditional lifestyle & 2.546 & -25.988 \\
\hline & Total & 3.511 & -44.161 \\
\hline
\end{tabular}

Source: own compilation (2020).

with the highest mean were as follows: Existence of the sea, Existence of many rivers, Presence of beautiful natural landscapes, Existence of forest, Existence of human perspectives, Existence of traditional lifestyle and handicrafts, and Abundance of agricultural products.

The reason why the pull factors scored higher in the $t$-test can be explained as follows. Despite the dry climate of Iran, the northern region of the country, especially Gilan province, has a temperate climate because of its geographical location. The forest cover and Hyrcanian forests along the water-rich rivers have made northern Iran a popular region which attracts a large part of the Iranian population every year. In fact, owing to its geographical location, Gilan has become an important tourist area in Iran and the tourism industry in this province has grown significantly.

According to the results in Table 4, the existing pull factors in Gilan province have played the most important role in travelling there. This is due to the environmental characteristics of Gilan.

The Kaiser-Meyer-Olkin (KMO) measure should be $>0.70$ and is inadequate if it is $<0.50$. The KMO test tells one whether or not enough items are predicted by each factor. The Bartlett test should be significant (i.e. a significance value of $<0.05$ ); this means that the variables are correlated highly enough to provide a reasonable basis for factor analysis (Leech et al. 2005).

Since the KMO coefficient was equal to 0.749 with a significance level of 0.000 , the results show the adequacy of sample size and the suitability of data for factor analysis. Bartlett's test of sphericity (496) was found to be significant at $p=0.000$ (Table 5). Based on the above statistical measures, the use of factor analysis was deemed appropriate.

Table 6 shows the results of factor analysis. The first factor was labelled 'nature-based tourism and spiritual renewal'. This factor, with an eigenvalue of 8.267 , has the highest percentage of explained variance equal to $23.684 \%$ and consists

Table 5. KMO and Bartlett's Test.

\begin{tabular}{|l|c|}
\hline $\begin{array}{c}\text { Kaiser-Meyer-Olkin measure of sampling } \\
\text { adequacy }\end{array}$ & 0.749 \\
\hline Approx. chi-square & $1,546.104$ \\
\hline Bartlett's test of sphericity $d f$. & 496 \\
\hline Sig. & 0.000 \\
\hline
\end{tabular}

KMO - Kaiser-Meyer-Olkin.

Source: own compilation (2020). 
Table 6. Results of factor analysis.

\begin{tabular}{|c|c|c|c|c|}
\hline \multirow[t]{2}{*}{ Factor } & \multirow[t]{2}{*}{ Variables included in the factor } & \multirow[t]{2}{*}{ Factor loadings } & \multicolumn{2}{|c|}{$\begin{array}{l}\text { Rotation sums of } \\
\text { squared loadings }\end{array}$} \\
\hline & & & Total & $\%$ of variance \\
\hline \multirow{8}{*}{ 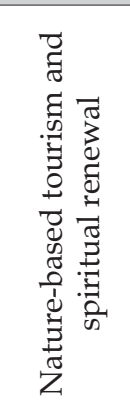 } & Desire to experience excitement and adventurous situations & 0.77 & \multirow{8}{*}{8.267} & \multirow{8}{*}{23.684} \\
\hline & $\begin{array}{l}\text { Overcoming stress and renewing mental health in space away } \\
\text { from usual tensions of life }\end{array}$ & 0.74 & & \\
\hline & Existence of sea & 0.73 & & \\
\hline & $\begin{array}{l}\text { Desire to escape from ongoing busy lfie and everyday homo- } \\
\text { geneity }\end{array}$ & 0.69 & & \\
\hline & Existence of many rivers & 0.65 & & \\
\hline & Existence of forest & 0.65 & & \\
\hline & Create happy and fun moments with family or friends & 0.69 & & \\
\hline & Presence of beautiful natural landscapes & 0.42 & & \\
\hline \multirow{8}{*}{ 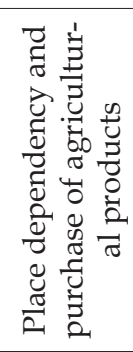 } & Sense of dependency & 0.66 & \multirow{8}{*}{5.621} & \multirow{8}{*}{18.173} \\
\hline & Existence of handicrafts & 0.65 & & \\
\hline & Abundance of agricultural product & 0.64 & & \\
\hline & Purchase of agricultural products at cheaper price & 0.61 & & \\
\hline & Direct purchase of agricultural products & 0.58 & & \\
\hline & Interest in visiting village of birthplace or family hometown & 0.52 & & \\
\hline & Desire to meet family, friends and relatives & 0.51 & & \\
\hline & Diverse agricultural activities & 0.58 & & \\
\hline \multirow{4}{*}{ 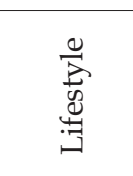 } & Existence of human perspectives & 0.54 & \multirow{4}{*}{3.492} & \multirow{4}{*}{14.792} \\
\hline & Opportunities to get acquainted with other cultures & 0.53 & & \\
\hline & Desire to interact with local residents & 0.42 & & \\
\hline & Existence of traditional lifestyle & 0.41 & & \\
\hline
\end{tabular}

Source: own compilation (2020).

of eight motivations, including Desire to experience excitement and adventurous situations, Overcoming stress and renewing the mental health in a space away from the usual tensions of life, Existence of sea, Desire to escape from the ongoing busy life and everyday homogeneity, Existence of many rivers, Existence of forest, Create happy and fun moments with your family or friends and Presence of beautiful natural landscapes.

Based on the results of factor analysis, the reason for naming the first factor as 'nature-based tourism and spiritual renewal' is that there is a direct relationship between nature and the human psyche, and one of the reasons for travelling to Gilan is the same stresses of living in big cities. Living conditions in big cities cause residents to be mentally stressed. Hence, nature-based tourism is a cure. Therefore, the natural environment has the necessary potential for spiritual renewal and most citizens in big cities choose Gilan for travel.

The second factor, which was labelled 'place dependency and the purchase of agricultural products' with an eigenvalue of 5.621, and the explained variance of $18.173 \%$, consists of eight motivations, including Sense of dependency, Existence of handicrafts, Abundance of agricultural products, Purchase of agricultural products at a cheaper price, Direct purchase of agricultural products, Interest in visiting a village of birthplace or family hometown, Desire to meet family, friends and relatives and Diverse agricultural activities.

The third factor, which was labelled 'lifestyle' with an eigenvalue of 3.492, and the explained variance of $14.792 \%$, consists of four motivations, including Existence of human perspectives, Opportunities to get acquainted with other cultures, Desire to interact with local residents and Existence of traditional lifestyle.

\section{Discussion}

This paper shows that both push and pull factors play an important role in travelling to Gilan. Since Gilan is considered as one of the tourist destinations among Iranian cities, the population from many parts of Iran travel to this region, 
although most trips to Gilan are from big cities. Neoliberal policies have recently dominated Iranian cities and posed many challenges to urban life. Lack of sufficient recreational spaces in large cities, environmental issues (air pollution, traffic, etc.), economic conditions of the community (in large cities, people spend a lot of time working) and sociological issues have caused citizens to spend stressful moments in cities. Hence, they are trying to escape from this unpleasant situation. Thus, the northern cities and primarily Gilan are the destinations of their travels. Gilan has been able to attract a large number of tourists due to its natural assets and beautiful landscapes.

The study showed that in addition to natural features, factors such as spiritual recovery, sense of belonging, purchase of agricultural products and cultural issues are the most important motivators for travelling to Gilan. The presence of pristine nature in these areas enables people to make a proper spiritual recovery. Some tourists have previously lived in Gilan and moved to other cities for various reasons. Owing to their sense of place, they visit Gilan again and review their past memories there. The existence of high-quality and local agricultural products also plays an important role in travelling to Gilan. Because of its geographical location, many agricultural products are produced there. These products are of high quality. Therefore, in addition to enjoying the pristine nature of Gilan, tourists also buy its agricultural products. Gilan is a historical region in which different lifestyles can be seen. The living culture in Gilan is very different and this is shown in its historical background. The lifestyle of the people here is unique. The existence of rural lifestyles attracts tourists. In general, we must say that there is a kind of coordination between the geographical, cultural and social characteristics of Gilan, which causes tourists to travel to this region. All the above instances show the importance of the Gilan region. Therefore, the development of tourism there is very important and can lead to the economic development of this region. In view of this fact, the following suggestions can be made for the development of tourism.

(1) The Iranian government should establish a unique ministry of tourism to cover all the potentials that exist in the country. Instead of a passive approach, the government should develop practical strategic plans to develop the tourism industry. The government can provide a tourism zoning in the form of a strategic tourism plan. This helps to identify the tourism potential of each region of Iran and take executive measures to develop the tourism industry. Gilan tourism will gain new power within this strategic plan. Furthermore, (2) the government can efficiently attract tourists by building international relations. In the past decade, movements in the tourism sector have been supported by the government, but now it can be stated that Iranian tourism is no longer among the government's priorities due to international sanctions and the pandemic. However, the government should not omit the tourism industry, it should rather focus on extensive national and international media advertisements for tourist attractions. (3) The government must strictly pursue media propaganda and normalise international relations for the entry of foreign tourists. Today, the media has become an arbitrary powerful tool in the world. Media, therefore, can introduce Gilan to the world and attract tourists to this region. (4) Another leading factor is to strengthen competitiveness capacity for tourism development in Gilan. Providing necessary and worldclass qualities will enable this region to compete with other similar destinations. Gilan will thrive on the arrival of tourists to the region. In general, tourism destination competition is critical for achieving the ideal position in the global tourism destination market and maintaining a competitive advantage. (5) Another leading challenge is with investments: no foreign and direct domestic investments in Gilan tourism is a challenge for mainstream tourism, especially in the accommodation sector, where the provision of products and services for international trade and leisure markets is inadequate. The public and private sectors must collaborate to promote the tourism industry in this region. The process of attracting investors is a key step in the development of Gilan tourism. Domestic and foreign investors must be inspired to invest in Gilan tourism. The government should offer incentive packages and facilitate organisational and institutional procedures for their presence in this sector. (6) Branding for Gilan nature tourism can be of great importance for introducing the attractions of these areas and inspire tourists to enjoy wonderful experiences amidst nature. 
Commercial branding is a powerful tool to make a difference and will create a kind of competitive advantage in the market. When Gilan is introduced as a particular brand, it will become the focus of media and communication spaces and will be known among tourists so that they will be motivated to visit this region.

\section{Conclusions}

The purpose of the paper was to identify the motivations of tourists travelling to Gilan province. In this regard, the pull and push factors affecting the trip to Gilan were investigated. In the first step, 20 surveyed motivations were classified into three main factors without considering pull and push factors and through factor analysis. Pull and push factors were examined through one-sample $t$-test. The results showed that the total average of pull motives is greater than that for push motives, but what is important in this regard is the existence of certain conditions at the origin of the travel that creates push motives for the travel, and Gilan province, as a tourism destination, has attracted tourists due to its characteristics. In the second step, based on the factor analysis, the first factor was called 'nature-based tourism and spiritual renewal'; the second and third factors were called 'place dependency and the purchase of agricultural products' and 'lifestyle' respectively. According to the results of the two tests, it can be concluded that according to the one-sample $t$-test, both the pull and push factors have been effective in travel motivation and the pulling role of Gilan has been more prominent; the results of the factor analysis also confirm this finding. The results of this research can be extended in the future. Hence, each of the motivations identified in this study, which were presented in the form of three factors (especially factors that scored high), can be studied separately by other researchers. The important point is that by determining the travel destinations, researchers can provide solutions to improve the destination and help tourism authorities to strengthen the tourism industry. In fact, identifying places tourists are interested in and then planning to manage those places is one of the most important topics that researchers can pursue.

\section{References}

Aghajani H., Azkia M., 2015. Sociological analysis of the impact of tourism industry on regional development of Gilan Province (Case Study: Rasht, Iran). Journal of Social Development Studies 7(4): 7-28.

Aghayarihir M., Karimzadeh H., Khaleghi A., 2018. Analysis of the factors affecting the decision on the migration of villagers in the territory of behavioral geography (Case Study: Sina Rural District). Journal of Rural Research 9(1): 42-57.

Al-Haj Mohammad B.A.M., Matsom A.P., 2010. An analysis of push and pull travel motivations of foreign tourists to Jordan. International Journal of Business and Management 5(12): 41-50. DOI 10.5539/ijbm.v5n12p41.

Arlinghaus R., Mehner T., 2004. A management-orientated comparative analysis of urban and rural anglers living in a metropolis (Berlin, Germany). Environmental Management 33: 331-344. DOI 10.1007/ s00267-004-0025-x.

Beard J., Ragheb M., 1983. Measuring leisure motivation. Journal of Leisure Research 15(3): 219-228. DOI 10.1080/00222216.1983.11969557.

Bideci M., Albayrak T., 2016. Motivations of the Russian and German tourists visiting pilgrimage site of Saint Nicholas Church. Tourism Management Perspectives 18: 10-13. DOI 10.1016/j.tmp.2015.12.022.

Bouzarjomehri Kh., 2014. Evaluation of social and cultural function of equipping, modernizing and integrating of rich field, case study: Neka. Journal of Geography and Urban and Regional Spatial Planning 12: 151-168.

Correia A., Oom do Valle P., Moço C., 2007. Modeling motivations and perceptions of Portuguese tourists. Journal of Business Research 60: 76-80. DOI 10.1016/j.jbusres.2005.10.013.

Crompton J.L., 1979. Motivations for pleasure vacation. Annuals of Tourism Research 6(4): 408-424. DOI 10.1016/01607383(79)90004-5.

Crompton J.L., McKay S.L., 1997. Motives of visitors attending festival events. Annals of Tourism Research 24(2): 425439. DOI 10.1016/S0160-7383(97)80010-2.

Deller D., 2010. Rural poverty, tourism and spatial heterogeneity. Annals of Tourism Research 37(1): 180-205. DOI 10.1016/j.annals.2009.09.001.

Devesa M., Laguna M., Palacios A., 2009. The role of motivation in visitor satisfaction: Empirical evidence in rural tourism. Tourism Management 31: 547-552. DOI 10.1016/j. tourman.2009.06.006.

Durbarry R., 2002. The economic contribution of tourism in Mauritius. Annals of Tourism Research 29(3): 862-865. DOI 10.1016/S0160-7383(02)00008-7.

Esfandiari S., Nabiyan S., 2000. The impact of poverty on immigration from village to city in Iran. Agricultural Economics and Development 26(101): 21-27.

Esichaikul R., 2012. Travel motivations, behavior and requirements of European senior tourists to Thailand. Revista de tourism yoatrimonio cultura 10(2): 47-58. DOI 10.25145/j.pasos.2012.10.026.

Francioni Kraftchick J., Byrd E.T., Canziani B., Gladwell N.J., 2014. Understanding beer tourist motivation. Tourism Management Perspectives 12: 41-47. DOI 10.1016/j. tmp.2014.07.001.

Gnoth J., 1997. Tourism motivation and expectation formation. Annals of Tourism Research 24(2): 283-304. DOI 10.1016/S0160-7383(97)80002-3.

Gu X., Sheng L., Yuen C.Y., 2019. Inbound tourism, hospitality business, and market structure. Journal of 
Hospitality \& Tourism Research 43(8): 1326-1335. DOI $10.1177 / 1096348019870574$.

Guha S., 2009. Motivational push factors for visiting reenactment sites. In: Partial fulfillment of the requirements for the degree master of science. The Faculty of the Department of Hospitality Recreation and Tourism Management San Jose State University, California.

Habibi F., Mehran Rahmati M., Karimi A., 2018. Contribution of tourism to economic growth in Iran's Provinces: GDM approach. Future Business Journal 4: 261-271. DOI 10.1016/j.fbj.2018.09.001.

He J.M., 2003. A study on rural tourism overseas. Tourism Tribune 18(1): 76-80.

Heitmann S., 2011. Tourist behaviour and tourist motivation In: Robinson P., Heitmann S., Dieke P. (eds), Research themes for tourism, Oxfordshire. CAB International, UK: 31-44. DOI 10.1079/9781845936846.0031.

Hua Y., Yoo J.J.-E., 2011. Travel motivations of Mainland Chinese travelers to the United States. Journal of China Tourism Research 7(4): 355-376. DOI 10.1080/19388160.2011.627000.

Huang S., 2010. Measuring tourism motivation: Do scales matter? Tourismos 5(1): 153-162.

Jang S., Bai B., Hu C., Wu C.-M.E., 2009. Affect, travel motivation, and travel intention: A senior market. Journal of Hospitality \& Tourism Research 33(1): 51-73.

Jang S., Cai L., 2002. Travel motivations and destination choice: A study of British outbound market. Journal of Travel \& Tourism Marketing 13(3): 111-133. DOI $10.1177 / 1096348008329666$.

Jang S.C., Wu C.M.E., 2006. Senior travel motivation and the influential factor: An examination of Taiwaness seniors. Tourism Management 27: 306-316. DOI 10.1016/j.tourman.2004.11.006.

Jomepour M., 2007. Relationship between the development level of villages in Tehran Province and migration to Tehran City. Quarterly Journal of Rural and Development 10(3): 55-27.

Kim J., Ritchie B.W., 2012. Motivation-based typology: An empirical study of golf tourists. Journal of Hospitality \& Tourism Research 36(2): 251-280. DOI $10.1177 / 1096348010388661$.

Kozak M., 2002. Comparative analysis of tourist motivations by nationality and destinations. Tourism Management 23: 221-232. DOI 10.1016/S0261-5177(01)00090-5.

Lai M.Y., Wang Y., Khoo-Lattimore C., 2020. Do food image and food neophobia affect tourist intention to visit a destination? The case of Australia. Journal of Travel Research 59(5): 928-949. DOI 10.1177/0047287519867144.

Lee Ch., Chang Ch.P., 2008. Tourism development and economic growth: A closer look at panels. Journal of Tourism Management 1(1): 110-182. DOI 10.1016/j.tourman.2007.02.013.

Leech N.L., Barrett K.C., Morgan G.A., 2005. SPSS for intermediate statistics: Use and interpretation, 2nd Edn. Lawrence Erlbaum Associates, Inc., Publishers, Mahwah, New Jersey. DOI 10.4324/9781410611420.

Liao C.-S., Chuang H.K., 2020. Tourist preferences for package tour attributes in tourism destination design and development. Journal of Vacation Marketing 26(2): 230-246. DOI 10.1177/1356766719880250.

Luo J.M., Ren L., 2020. Qualitative analysis of residents' generativity motivation and behaviour in heritage tourism. Journal of Hospitality and Tourism Management 45: 124-130. DOI 10.1016/j.jhtm.2020.08.005.
Macintosh R.W., Goeldner C.R., 1986. Principles, practices, philosophies. Wiley, New York.

Mahmoudzadeh S.M., Mirhashemi A., Mir M., Anbarfurush F., 2014. Identification and prioritization of push and pull motivational factors affecting the development of war tourism (Case Study: Operational areas of Khuzestan province). Journal of Planning and Development Tourism 1 : 110-129.

Matiza T., Slabbert E., 2020. South Africa's place brand: A marketing axiom to South Africa as a tourism destination? Journal of Destination Marketing \& Management 15: 100380. DOI 10.1016/j.jdmm.2019.100380.

Moureh J., 1994. Urban Spaces - Design and Management, Routledge, London.

Noriko I., Mototsugu F., 2007. Impacts of tourism and fiscal expenditure to remote islands: The case of the Amami islands in Japan. Applied Economics Letter 14: 661-666. DOI $10.1080 / 13504850500461423$.

O'Leary S., Deegan J., 2005. Ireland's image as a tourism destination in France: Attribute importance and performance. Journal of Travel Research 43(3): 247-256. DOI $10.1177 / 0047287504272025$.

Pan S., Ryan C., 2007. Usage-motivations and determinants of satisfaction: The case of Pirongia Forest Park, New Zealand. Journal of Sustainable Tourism 15(3): 288-308. DOI 10.2167/jost662.0.

Park D.B., Yoon Y.S., 2009. Segmentation by motivation in rural tourism: A Korean case study. Tourism Management 30(1): 99-108. DOI 10.1016/j.tourman.2008.03.011.

Pereira V., Gupta J.J., Hussain S., 2019. Impact of travel motivation on tourist's attitude toward destination: Evidence of mediating effect of destination image. Journal of Hospitality \& Tourism Research. DOI 10.1177/1096348019887528.

Podoshen J.S., 2013. Dark tourism motivations: Simulation, emotional contagion and topographic comparison. Tourism Management 35: 263-271. DOI 10.1016/j.tourman.2012.08.002.

Prayag G., Hosany S., 2014. When Middle East meets West: Understanding the motives and perceptions of young tourists from United Arab Emirates. Tourism Management 40: 35-45. DOI 10.1016/j.tourman.2013.05.003.

Qelichi M.M., Murgante B., Yousefi Feshki M., Zarghamfard M., 2017. Urbanization patterns in Iran visualized through spatial auto-correlation analysis. Spatial Information Research 25: 627-633. DOI 10.1007/s41324-017-01280.

Rid W., Ezeuduji I.O., Pröbstl-Haider U., 2014. Segmentation by motivation for rural tourism activities in The Gambia. Tourism Management 40: 102-116. DOI 10.1016/j.tourman.2013.05.006.

Ridderstaat J., Croes R., Nijkamp P., 2014. Tourism and longrun economic growth in Aruba. International Journal of Tourism Research 16(5): 472-487. DOI 10.1002/jtr.1941.

Rivera D., Chandler J.A., Winslow H., 2010. Developing a profile of visitors at a North Carolina wine festival: Pilot test, Spring 2009. Consortium Journal of Hospitality $\mathcal{E}$ Tourism 14(2): 5 .

Ryan C., Gu H., Zhang W., 2009. The context of Chinese tourism: An overview and implications for research. In: Ryan C., Gu H. (eds), Tourism in China: Destination, cultures and communities. Routledge, New York London: 327-336.

Safavi S.R., Skandarinodeh M., Alizadeh M., Khoshdelan M., 2017. Study of employment status in the tourism sector (case of Gilan province). Geographic Quarterly Journal 17(60): 21-38 
Sangpikul A., 2009. A comparative study of travel motivations between Asian and European tourists to Thailand. Journal of Hospitality and Tourism 7(1): 22-43.

Schubert F.S., Brida J.G., Risso W.A., 2010. The impacts of international tourism demand on economic growth of small economies dependent of tourism. Tourism Management 32(2): 377-385. DOI 10.1016/j.tourman.2010.03.007.

Seetanah B., 2011. Assessing the dynamic economic impact of tourism for island economic. Annals of Tourism Research 38(1): 291-308. DOI 10.1016/j.annals.2010.08.009.

Shakooei H., 1979. Urban environment. Pressed by University of Tabriz, Tabriz.

Shamsoddini A., Gorjian P., 2010. Effective factors in migrating villagers to cities, emphasizing migration network (case: Rostam-Do Village). Geographic Landscape 5(11): 87-105.

Sharpley R., 2008. Tourism, tourists and society. Routledge, London.

Sharpley R., Telfer D.J., 2015. Tourism and development: Concepts and issues. Channel View Pulications, Bristol, 2015 WTTC. Economic Research. WTTC, London.

Shia I., 2003. The necessity of urban management transformation in Iran. Journal of Geography and Development, Spring and Summer 3: 37-62.

Taher S.H.M., Jamal S.A., Sumarjan N., Aminudin N., 2015. Examining the structural relations among hikers' assessment of pull-factors, satisfaction and revisit intentions: The case of mountain tourism in Malaysia. Journal of Outdoor Recreation and Tourism 12: 82-88. DOI 10.1016/j. jort.2015.11.012.

Truong T.L.H., Lenglet F., Mothe C., 2017. Destination distinctiveness: Concept, measurement, and impact on tourist satisfaction. Journal of Destination Marketing \& Management 1-18. DOI 10.1016/j.jdmm.2017.04.004.

UNWTO, 2012. Yearbook of tourism statistics. UNWTO Publication. Online: www.unwto.org.

Utama I.G., Darma Putra I.N., Suradnya I.M., 2014. Confirmation on the motivation and satisfaction model of for- eign senior tourists. International Journal of Scientific $\mathcal{E}$ Engineering Research 5(8): 1206-1215.

Uysal M., Jurowski C., 1994. Testing the push and pull factors. Annals of Tourism Research 21(4): 844-846. DOI 10.1016/0160-7383(94)90091-4.

Vigolo V., Simeoni F., Cassia F., Ugolini M.M., 2018. The effects of travel motivation on satisfaction: The case of older tourists. International Journal of Business and Social Science 9: 19-30.

Wang Y.C., 2006. The new form and model of development of rural tourism in China. Tourism Tribune 21(4): 6-8.

Wu M.Y., Pearce P.L., 2014. Chinese recreational vehicle users in Australia: A netnographic study of tourist motivation. Tourism Management 43: 22-35. DOI 10.1016/j. tourman.2014.01.010.

Yıldız M.S., Khan M.M., 2019. Factors affecting the choice of medical tourism destination: A case study of medical tourists from the Arab Region in Turkey. Journal of Heal th Management 21(4): 465-475. DOI 10.1177/0972063419884396.

Yosefi M., Marzuki A., 2015. An analysis of push and pull motivational factors of international tourists to Penang, Malaysia. International Journal of Hospitality \& Tourism 16: 40-56. DOI 10.1080/15256480.2015.991987.

Yousaf S., Xiucheng F., 2018. Halal culinary and tourism marketing strategies on government websites: A preliminary analysis. Tourism Management 68: 423-443. DOI 10.1016/j.tourman.2018.04.006.

Zarghamfard M., Meshkini A., Pourahmad A., Murgante B., 2019. The pathology of housing policies in Iran: A criterion-based analysis. International Journal of Housing Markets and Analysis 13(3): 453-473. DOI 10.1108/IJHMA-06-2019-0066.

Zhang Y., Peng Y., 2014. Understanding travel motivations of Chinese tourists visiting Cairns, Australia. Journal of Hospitality and Tourism Management 21: 44-53. DOI 10.1016/j.jhtm.2014.07.001. 